Seasonal fluctuations of bacterial community diversity in agricultural soil and experimental validation by laboratory disturbance experiments

\author{
Journal Article \\ Author(s): \\ Meier, Christoph; Wehrli, Bernhard; Meer, Jan Roelof van der \\ Publication date: \\ 2008 \\ Permanent link: \\ https://doi.org/10.3929/ethz-b-000010273
}

Rights / license:

In Copyright - Non-Commercial Use Permitted

Originally published in:

Microbial Ecology 56(2), https://doi.org/10.1007/s00248-007-9337-8 


\title{
Seasonal Fluctuations of Bacterial Community Diversity in Agricultural Soil and Experimental Validation by Laboratory Disturbance Experiments
}

\author{
Christoph Meier • Bernhard Wehrli • \\ Jan Roelof van der Meer
}

Received: 2 July 2007 / Accepted: 25 October 2007 / Published online: 25 November 2007

(C) Springer Science + Business Media, LLC 2007

\begin{abstract}
Natural fluctuations in soil microbial communities are poorly documented because of the inherent difficulty to perform a simultaneous analysis of the relative abundances of multiple populations over a long time period. Yet, it is important to understand the magnitudes of community composition variability as a function of natural influences (e.g., temperature, plant growth, or rainfall) because this forms the reference or baseline against which external disturbances (e.g., anthropogenic emissions) can be judged. Second, definition of baseline fluctuations in complex microbial communities may help to understand at which point the systems become unbalanced and cannot return to their original composition. In this paper, we examined the seasonal fluctuations in the bacterial community of an agricultural soil used for regular plant crop production by using terminal restriction fragment length polymorphism profiling (T-RFLP) of the amplified 16S ribosomal ribonucleic acid (rRNA) gene diversity. Cluster and statistical analysis of T-RFLP data showed that soil
\end{abstract}

Electronic supplementary material The online version of this article (doi: 10.1007/s00248-007-9337-8) contains supplementary material, which is available to authorized users.

C. Meier · B. Wehrli ·. R. van der Meer

Swiss Federal Institute for Aquatic Science and Technology (Eawag), CH-8600 Dübendorf, Switzerland

B. Wehrli

Institute of Biogeochemistry and Pollutant Dynamics,

ETH Zürich, Switzerland

J. R. van der Meer $(\bowtie)$

Department of Fundamental Microbiology,

University of Lausanne,

Bâtiment Biophore, Quartier Unil-Sorge,

1015 Lausanne, Switzerland

e-mail: janroelof.vandermeer@unil.ch bacterial communities fluctuated very little during the seasons (similarity indices between 0.835 and 0.997 ) with insignificant variations in $16 \mathrm{~S}$ rRNA gene richness and diversity indices. Despite overall insignificant fluctuations, between 8 and $30 \%$ of all terminal restriction fragments changed their relative intensity in a significant manner among consecutive time samples. To determine the magnitude of community variations induced by external factors, soil samples were subjected to either inoculation with a pure bacterial culture, addition of the herbicide mecoprop, or addition of nutrients. All treatments resulted in statistically measurable changes of T-RFLP profiles of the communities. Addition of nutrients or bacteria plus mecoprop resulted in bacteria composition, which did not return to the original profile within 14 days. We propose that at less than $70 \%$ similarity in T-RFLP, the bacterial communities risk to drift apart to inherently different states.

\section{Introduction}

The complexity of most microbial communities, both in terms of species diversity and their abundance, has eluded facile analysis. Yet, to understand their functioning and resilience to external changes, it is desirable to assess the community composition, quantify individual microbial population sizes, and study fluctuations thereof $[17,42]$. Especially in complex systems like soil, determination of the microbial diversity is a daunting task [3]. Estimations of the bacterial diversity in a gram of soil vary between some thousand species, as determined from extensive clone libraries [45] and from deoxyribonucleic acid (DNA) renaturation experiments [41], to more than a million [11]. Despite important advances in genome sequencing technologies, which may one day tackle the complete sequence diversity in a soil bacterial commu- 
nity, for many different purposes, such as bioremediation efforts or monitoring chemical pollution effects, it is necessary to have easy monitoring methods to track community and diversity changes over time.

Cultivation-independent molecular profiling techniques have proven to be very valuable for effect monitoring on microbial communities. Examples of useful DNA-based profiling techniques are terminal restriction fragment (tRF) length polymorphisms (T-RFLPs) [27, 29], denaturing gradient gel electrophoresis (DGGE) [7, 12, 30, 32, 43], ribosomal intergenic spacer analysis (RISA) [9], and singlestrand conformation polymorphism (SSCP) [19, 24, 39]. Most frequently, these profiling techniques assess bacterial diversity via $16 \mathrm{~S}$ ribosomal ribonucleic acid (rRNA) gene diversity in a pool of fragments amplified from total community-derived DNA in the polymerase chain reaction (PCR). Typically, DNA community profiling techniques have a genus-level resolution [8] and are thought to detect bacterial populations with at least $1 \%$ relative abundance in a sample [22]. On the other hand, PCR-based approaches can lead to amplification bias and artifacts [10]. Obviously, this $1 \%$ is lower coverage than large-scale sequencing of clone libraries can give, but profiling techniques are faster and therefore more suitable for field-scale experiments, where replication and increased sampling frequency are important [17].

Despite abundant usage of DGGE, SSCP, and T-RFLP in a wide variety of microbial ecosystems including agricultural soil, it is not very clear what the natural and temporal fluctuations in soil microbial communities are. This seems important information for subsequent effect studies to be based upon. Studies on a number of long-term field sites have suggested that soil microbial communities develop significantly different in time (5-20 years) as a function of plant type [22, 2] or agricultural practice [44]. Bacterial communities in extremely perturbed or technical environments (e.g., reactors or enrichment cultures) also change measurably but not always consistently as a function of, e.g., pollutant concentration $[1,13,28]$, pollutant, or soil type $[13,25,31]$. Bacteria inoculation, on the other hand, did not lead to detectable bacterial community changes in a soil bioremediation experiment to enhance 2-nitrophenol degradation [34]. Natural or seasonal variations themselves, however, are less well described. Buckley and Schmidt [3] detected up to fourfold variations in the relative ratio of taxonomic units as determined by quantitative filter hybridizations on RNA extracted from agricultural soils sampled on four occasions during 2 years. Lipson and Schmidt [26] detected significant community shifts in alpine soil bacterial communities after snow melt by using clone library analysis, leveling up to a twofold increase or decrease per taxonomic group. Phospholipid fatty acid profiling from agricultural soil microbial communities also suggested significant seasonal changes $[15,2]$, although this is not necessarily due to a change in community composition but to microbial physiology.

In this paper, we focused on determining the sensitivity of T-RFLP to measure relative population variations in a regular agricultural soil bacterial community. Although the focus of this study is the bacterial community, the soil fungal communities should not be neglected [38]. The T-RFLP method for 16S rRNA gene diversity in soil was recently compared with community-level substrate utilization methods, with RISA, and with sequencing of extensive clone libraries, and it was concluded that T-RFLP was sufficiently representative and highly sensitive to detect community differences while maintaining rapidity [17]. T-RFLP profiling would thus form an ideal method to investigate the seasonal variability of soil bacterial communities, which could be used as a baseline against which potential effects of external influences might be better assessed. The first objective of our work, therefore, was to determine such a baseline of natural variability in a regular agricultural soil bacterial community. Hereto, we sampled and analyzed the bacterial community diversity of one agricultural soil on several occasions during 1 year. The second objective was to place the magnitude of community variations in perspective with experimentally induced community changes by subjecting the same soil in microcosms to artificial disturbances, notably bacteria inoculation, application of herbicide or nutrients.

\section{Materials and Methods}

\section{Soil Sampling and Site Description}

The soil used for the community analysis was collected from an agricultural field $\left(47^{\circ} 24^{\prime} 18.03^{\prime \prime} \mathrm{N}, 8^{\circ} 36^{\prime} 36.64^{\prime \prime} \mathrm{E}\right.$, $432 \mathrm{~m}$ altitude) near the Swiss Federal Institute for Aquatic Science and Technology (Eawag, Dübendorf, Switzerland), where crop rotation is applied. Values of major soil chemical parameters were: $5.1 \%$ organic $\mathrm{C}, 60 \% \mathrm{SiO}_{2}$, $11.7 \% \mathrm{Al}_{2} \mathrm{O}_{3}, 2.4 \% \mathrm{MgO}, 4.8 \% \mathrm{Fe}_{2} \mathrm{O}_{3}, \mathrm{pH}-\mathrm{H}_{2} \mathrm{O}: 7.6$, pH$\mathrm{KCl}$ : 7.0. During the year of sampling (2002-2003), maize was grown in the summer season, followed by winter lettuce. For mean temperature and rainfall, consult Table S1 in the Supplementary online material. For each sampling a total of $\sim 500 \mathrm{~g}$ of surface bulk soil (depth $0-5 \mathrm{~cm}$, excluding plants or plant roots) was pooled from randomly collected 50-g aliquots within a $1-\mathrm{m}^{2}$ area and transferred to a sterile $500-\mathrm{mL}$ Schott flask (Milian SA, Genève, Switzerland). The same field was sampled at the approximate same spot (within $1 \mathrm{~m}^{2}$ ) at 12 occasions during the 2 subsequent years, but only eight samples produced interpretable T-RFLP data. Three aliquots of $5 \mathrm{~g}$ (fresh weight) were 
prepared from each pooled sample. Soil was neither dried nor sieved before community DNA isolation. Total community DNA was isolated and purified from aliquots immediately after sample collection. For community disturbance experiments, the same spot was sampled on one occasion in Spring 2003.

\section{Soil Microbial Community Total DNA Isolation}

Total DNA was isolated from 2- or 5-g quantities of soil by a bead-beating procedure essentially as described by Bürgmann et al. [4], followed by standard phenol/chloroform/isoamylalcohol extraction and ethanol/sodium acetate precipitation [37]. After recovery of the DNA by centrifugation for $20 \mathrm{~min}$ at $13,000 \mathrm{rpm}$, it was washed with icecold $70 \%$ ethanol, dried and resuspended in $50 \mu \mathrm{L}$ TrisEDTA (TE) buffer (10 mM Tris $\mathrm{pH}$ 8.0, $1 \mathrm{mM}$ ethylenediamine tetraacetic acid [EDTA]). The DNA was further purified according to the Geneclean ${ }^{\circledR}$ III protocol (Q-Bio gene, Montréal, Québec, Canada), finally eluted in $50 \mu \mathrm{L}$ of sterile demineralized water, after which a small aliquot was visualized by electrophoresis in ethidium bromidestained agarose gels. DNA concentration was determined by fluorimetry by comparison to a dilution series of purified phage $\lambda$-DNA. Typical amounts recovered per gram of soil were in the range of 4 to $10 \mu \mathrm{g}$. The purified DNA was then used for T-RFLP and RISA analyses without further cleaning steps.

\section{T-RFLP and RISA Analysis}

For T-RFLP, 16S rRNA gene fragments were amplified from microbial community DNA by using the bacterial primers 16S 8F (5'-AGAGTTTGATCCTGGCTCAG-3') at position 8-27 (E. coli SSU rRNA, GenBank accession number J01695) and 16S 926R (5'-CCGTCAATTCCTT TRAGTTT-3', position 926 reverse) [34]. The primers S-DBact-1522-b-S20 and L-D-Bact-132-a-A-18 were used to amplify the intergenic spacer between the $16 \mathrm{~S}$ and $23 \mathrm{~S}$ rRNA genes [36]. Primers 16S 926R and S-D-Bact-1522-bS20 were labeled with the infrared dye IRDye ${ }^{\mathrm{TM}} 800$ (hereafter, IRD-800, MWG Biotech, Engersberg, Germany), and the primer $16 \mathrm{~S} 8 \mathrm{~F}$ was marked with IRDye ${ }^{\mathrm{TM}}$ 700 (hereafter, IRD-700). Each $50-\mu \mathrm{L}$ PCR mixture contained $9 \mu \mathrm{L}$ of PCR buffer (Sigma Chemical, St. Louis, MO), $0.4 \mu \mathrm{L}$ deoxynucleotide triphosphates ( $25 \mathrm{mM}$ each), $0.25 \mu \mathrm{L}$ Taq DNA polymerase (Sigma), and between 30 and $35 \mu \mathrm{L}$ sterile demineralized $\mathrm{H}_{2} \mathrm{O}$. Both primers were added in $1 \mu \mathrm{L}$ volume at $100 \mathrm{pmol}$ each; $1 \mu \mathrm{L}$ of target DNA ( $\sim 50 \mathrm{ng}$ ) and another $7-\mu \mathrm{L}$ sterile $\mathrm{H}_{2} \mathrm{O}$ completed the PCR mixture. The cycling conditions for the amplification of 16S rRNA genes were the following: (1) one cycle of 3 min denaturation at $93.5^{\circ} \mathrm{C}$, (2) 35 cycles, of each $30 \mathrm{~s}$ at $93.5^{\circ} \mathrm{C}, 30 \mathrm{~s}$ at $49^{\circ} \mathrm{C}$, and $2 \mathrm{~min}$ at $72^{\circ} \mathrm{C}$, and (3) a final extension cycle during $5 \mathrm{~min}$ at $72^{\circ} \mathrm{C}$ (Genius FGENO5TD thermocycler, Tecne, Burlington, NJ). The PCR conditions for RISA are described elsewhere [35]. Three independent PCR reactions were performed per soil sample. The correct size and quantity of the PCR products were verified by agarose gel electrophoresis before continuing with the T-RFLP or RISA analysis.

For T-RFLP analysis, the amplified 16S rRNA gene fragments, which were labeled at either end with IRD-800 or IRD-700, were digested using the restriction enzyme HaeIII for $2 \mathrm{~h}$ at $37^{\circ} \mathrm{C}$ (Fermentas International, Burlington, Ontario, Canada). Subsequently, the DNA fragments were concentrated by ethanol and sodium acetate precipitation and recovered by centrifugation. The DNA pellet was resuspended in a volume of 6 (for T-RFLP) or $12 \mu \mathrm{L}$ (for RISA) of TE buffer (pH 8.0). After the addition of 4.5 (for T-RFLP) or $9 \mu \mathrm{L}$ (for RISA) of loading buffer (containing 95\% formamide, $20 \mathrm{mM}$ EDTA, and $0.05 \%$ acidic fuchsine red), the samples were denatured for $3 \mathrm{~min}$ at $93.5^{\circ} \mathrm{C}$ and immediately transferred to ice.

The DNA fragments were separated according to their size by electrophoresis on 25 -cm-long polyacrylamide gels on a LI-COR 4200L sequencer (LI-COR, Lincoln, NE), using Tris-borate-EDTA buffer [37] at a voltage of $1,500 \mathrm{~V}$ and a running temperature of $45^{\circ} \mathrm{C}$. This instrument has the advantage that both IRD-700 and IRD800 markers can be detected simultaneously. Data were cropped and stored as TIFF image files.

\section{Bacteria Cultivation}

Sphingomonas herbicidivorans $\mathrm{MH}$ was used to inoculate soil aliquots for the disturbance experiments [18]. Strain $\mathrm{MH}$ is able to grow on phenoxyalkanoic acid herbicides, such as mecoprop (2-(4-chloro-2-methylphenoxy)propionic acid), as sole carbon and energy source [20]. The strain was grown at $30^{\circ} \mathrm{C}$ in $5 \mathrm{~mL}$ complex medium [46] in baffled Erlenmeyer flasks shaken at $180 \mathrm{rpm}$. Cells were harvested during the exponential phase, centrifuged for $5 \mathrm{~min}$ at $7,500 \times g$, washed once with phosphate-buffered saline (PBS; the solution contains $137 \mathrm{mM} \mathrm{NaCl}, 2.7 \mathrm{mM} \mathrm{KCl}$, $4.3 \mathrm{mM} \mathrm{Na} 2 \mathrm{HPO}_{4} 7 \mathrm{H}_{2} \mathrm{O}, 1.4 \mathrm{mM} \mathrm{KK_{2 }} \mathrm{PO}_{4}, \mathrm{pH}$ 7.3) to remove nutrients, and pelleted again by centrifugation. Finally, the cells were resuspended in $200 \mu \mathrm{L}$ sterile demineralized $\mathrm{H}_{2} \mathrm{O}$ to an approximate optical density of $\mathrm{OD}=0.6$ and added to $2 \mathrm{-g}$ soil aliquots in sterile $50-\mathrm{mL}$ capped polypropylene tubes.

\section{Disturbance Experiments and Sensitivity Analyses}

To test the sensitivity of T-RFLP to detect changes in microbial community composition, soil sample aliquots 
were subjected to different perturbations. Disturbance experiments were conducted with freshly collected soil (see above) divided in aliquots of $2 \mathrm{~g}$ in $50-\mathrm{mL}$ sterile capped polypropylene tubes (Techno Plastics Products AG, Trasadingen, Switzerland), incubated at $25^{\circ} \mathrm{C}$ for up to 2 weeks in three replicate series at $\sim 70 \%$ water-holding capacity. Individual tubes were sacrificed completely for total community DNA isolation after $0,1,2,4,7$, and 14 days of incubation. The following treatments were applied: addition of (1) nutrient broth (NB), (2) $S$. herbicidivorans strain $\mathrm{MH}$ at $10^{9}$ cells per gram soil (B, bacteria), (3) a mixture of mecoprop and strain $\mathrm{MH}$ (BM, bacteria and mecoprop), and (4) pure water as a control (S, soil water). For nutrient addition, $200 \mu \mathrm{L}$ of NB solution (Biolife, Milan, Italy) were pipetted to each of the $50-\mathrm{mL}$ tubes with $2 \mathrm{~g}$ of soil. Strain $\mathrm{MH}$ was supplied in $200 \mu \mathrm{L}$ of sterile demineralized water per aliquot of $2 \mathrm{~g}$ of soil and 50-mL tube. Mecoprop was added as $200-\mu \mathrm{L}$ aqueous solution of both enantiomers ([R,S]-2-[4-chloro-2-methyl-phenoxypropanoic acid]) at $100 \mathrm{mg} / \mathrm{L}$ each (Fluka, Buchs, Switzerland). In case of the addition of $S$. herbicidivorans strain $\mathrm{MH}$ and mecoprop simultaneously, the bacteria were resuspended in $200 \mu \mathrm{L}$ of mecoprop solution and added to $2 \mathrm{~g}$ of soil. As a negative control, $200 \mu \mathrm{L}$ of demineralized water was added per soil aliquot.

\section{Data Analysis}

The TIFF image files containing the community T-RFLP or RISA profiles were further analyzed using the BASE IMAGIR $^{\text {TM }}$ and GENE IMAGIR ${ }^{\text {TM }} 4.03$ software (Scanalytics, Fairfax, VA) to determine the number, length, and relative intensity of each of the tRFs in a sample. Output text files were further processed in Microsoft Excel. Accurate determination of tRFs was only possible in the size range of 100 to $700 \mathrm{bp}$, and bands outside this range were excluded from the analysis. Band intensities ("peak area") were normalized by dividing each band's absolute intensity by the total intensity of bands per lane. Peaks below $0.01 \%$ of the sum of all peak intensities were not considered. Diversity indices were calculated from the presence/absence and relative band intensities per sample using the formula, diversity index $=1-\sum\left(p_{\mathrm{i}}\right)^{2}$, where $p_{\mathrm{i}}$ is the relative intensity of each individual band divided by the sum of the relative intensities of all fragments per lane. Principal components analysis (PCA) was performed using the subroutines "dudi.pca" and "prcomp" in the statistical program R (http://www.r-project.org). Sample clustering was performed on Euclidean distance matrices calculated from the dataset of relative band intensities by using "agnes" in the package "cluster" of R. Distance matrices were compared in a Mantel test using Monte Carlo permutations with help of the program "mantel.rtest," which is part of the package "ade4" [5]. To test significance of clusterings, we performed bootstrapping by resampling distance matrices produced by "agnes" in a small subroutine written for this purpose. Consensus clusters were calculated from the bootstrapping output in the program "consense," which is a part of the Phylip 3.66 package. Branching frequencies were then added to the original "agnes"-input cluster for bootstrapping.

\section{Results}

Seasonal Bacterial Community Variability Studied from Polymorphisms in Amplified 16S rRNA Gene Fragments

The variability in bacterial community structure in an agricultural soil was studied by T-RFLP and RISA during 1 year by sampling eight times at approximately the same location (Table 1). If the bacterial community of the site would fluctuate in response to the seasons or be affected by human activities (e.g., plowing, cultivation) during the year, we expected that this would result in a change of individual bacterial population sizes making up the community and, thus, in different relative amounts of population DNA and 16S rRNA genes among the total community-derived DNA. A double-end-labeled T-RFLP system was used here to simultaneously extract a more optimal amount of data from each sample. Around $37 \mathrm{tRF}$ could be detected in the IRD-800 gel images produced with labeled primer 926R (Fig. 1a, Table 1), whereas 74-82 bands were distinguishable on gels with IRD-700-labeled fragments (primer 8F) albeit seemingly concentrated in a smaller size "region" (Fig. 1b). At first sight, the profiles did not show much variability in samples taken at different time points, except for an intensity increase of the fragments at $290 \mathrm{bp}$ in panel a1 (lanes 6ab) and at $610 \mathrm{bp}$ in panel b1 (lanes 6ab). It cannot be excluded that some tRFs would be artifacts from PCR [10]. Pearson's similarity indices within replicates varied between 0.835 and 0.997 , the IRD-700 analysis being overall less reproducible than the IRD-800-based one (Table 1). Examples of the development of relative average peak intensity for selected individual bands throughout the time period of analysis (Fig. 1c) reinforced the visual trend that little variation occurred in many of the bands but that other individual tRFs varied significantly throughout the season. Pairwise comparisons between subsequent sampling pairs in time resulted in 10 to 41 bands out of 125 of the total combined dataset (IRD-700) or between 9 and 12 from 37 total tRFs (IRD-800) being significantly different in intensity $(P<0.05, t$ test, Table 2$)$. Pairwise sample similarities were lower than within sample replicate similar- 
Table 1 Diversity statistics calculated from T-RFLP and RISA profiles of 16S rRNA genes amplified from agricultural soil DNA

\begin{tabular}{|c|c|c|c|c|c|c|c|c|c|}
\hline \multirow[t]{2}{*}{ Method } & \multirow[t]{2}{*}{ Index } & \multicolumn{8}{|c|}{ Sample, time (days) ${ }^{a}$} \\
\hline & & A, 0 & $\mathrm{~B}, 14$ & C, 39 & $\mathrm{D}, 50$ & $E, 65$ & F, 168 & G, 299 & $\mathrm{H}, 317$ \\
\hline \multirow[t]{2}{*}{ T-RFLP ${ }^{\mathrm{b}}$} & $S(700)^{c}$ & 77 & 76 & 76 & 74 & 76 & 74 & 79 & 82 \\
\hline & $\mathrm{S}(800)$ & 36 & 36 & 36 & 36 & 36 & 36 & 37 & 37 \\
\hline RISA & $\mathrm{S}(800)$ & $-{ }^{\mathrm{d}}$ & 43 & - & - & 42 & 46 & - & 44 \\
\hline \multirow[t]{2}{*}{ T-RFLP } & $\mathrm{D}(700)^{\mathrm{e}}$ & 0.966 & 0.970 & 0.974 & 0.970 & 0.965 & 0.968 & 0.967 & 0.965 \\
\hline & $\mathrm{D}(800)$ & 0.937 & 0.934 & 0.931 & 0.934 & 0.931 & 0.936 & 0.936 & 0.929 \\
\hline RISA & $\mathrm{D}(800)$ & - & 0.944 & - & - & 0.932 & 0.943 & - & 0.938 \\
\hline \multirow[t]{2}{*}{ T-RFLP } & $\operatorname{Sim}(700)^{f}$ & $0.987 \pm 0.004$ & $0.918 \pm 0.040$ & $0.835 \pm 0.072$ & 0.857 & $0.977 \pm 0.011$ & 0.973 & $0.927 \pm 0.039$ & 0.927 \\
\hline & $\operatorname{Sim}(800)$ & $0.997 \pm 0.001$ & $0.996 \pm 0.000$ & $0.996 \pm 0.001$ & 0.992 & $0.980 \pm 0.012$ & 0.994 & $0.987 \pm 0.007$ & 0.979 \\
\hline
\end{tabular}

${ }^{\text {a }}$ Time points of soil collection starting from day 0 on July 12002 (A). Sampling dates of other samples: B, July 15, C, August 9, D, August 30, E, September 14, F, December 12, G, February 25 2003, H, May 142003

${ }^{\mathrm{b}}$ T-RFLP Agricultural soil DNA analyzed with T-RFLP to study the natural variation of microbial community, RISA same soil DNA analyzed with RISA.

${ }^{\mathrm{c}}$ Phylotype richness, $S$, calculated as the total number of distinct tRFs and IGS sizes (between 100 and $700 \mathrm{bp}$ ) in a profile

${ }^{\mathrm{d}}$ Not determined

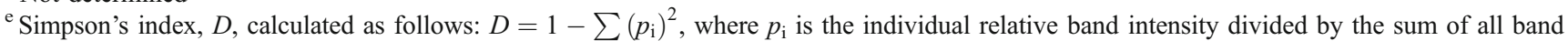
intensities per lane

${ }^{\mathrm{f}}$ Average Pearson's similarity coefficient, Sim, among replicates \pm average deviation (if more than two replicates)

ities and fluctuated between 0.417 and 0.989 , the IRD-800 dataset bearing overall higher similarities (Table 2). Intensity fluctuations were also higher in IRD-700- than IRD-800derived tRFs (from 8 to 19 tRFs being 200-fold less to 358fold more intense in subsequent samples for the IRD-700 channel, Table 2). Very few bands consistently varied throughout all samples except one tRF (i.e., IRD-700 $320 \mathrm{bp}$, more than fivefold in five of eight datasets). Between 1 and 13 newly appearing or disappearing tRFs were scored between consecutive time samples (IRD-700 data, Table 2) with a tendency of increasing differences around sample $\mathrm{F}$.

To consolidate the observations made with T-RFLP, a subset of the same soil DNA samples was again analyzed via RISA, which targets a different region as T-RFLP. The four samples showed a highly consistent number of 42 to 46 discrete bands (Fig. S1). The Simpson's diversity indices and phylotype richness calculated from T-RFLP and RISA data were remarkably stable for all samples, except for some tiny but insignificant variations (Table 1). Despite individual fragment intensity fluctuations, therefore, both T-RFLP and RISA data suggested that no changes in the total diversity of the soil microbial community took place during the sampling period.

\section{Principal Components and Clustering Analysis}

To analyze overall community fluctuations in more detail, we performed PCA and clustering for each of the datasets (IRD-700 and IRD-800 derived relative band intensities in T-RFLP). Two components were sufficient to explain 86.7 (IRD-700) and $97.6 \%$ (IRD-800) of the total variation
(Fig. 2). With few exceptions, sample replicates grouped relatively close together in the PCA plot, showing that there was on average little variation when all tRFs in the sample were taken into account (Fig. 2). Clustering analysis of distance matrices on both datasets confirmed that most triplicates grouped very closely together with a very small Euclidean distance between triplicates (Fig. 3). Bootstrapping analysis showed that most branchings between sample triplicates were not statistically significant (Fig. 3) and thus that samples taken at different points in time cannot be said to differ. Notable outliers in PCA were the samples F1/F2 for the IRD-700 dataset and $\mathrm{H} 1 / \mathrm{H} 2$ for the IRD-800 dataset. Because there is too little congruency between both datasets (Mantel test observation 0.42, $P=0.03$, Table 3), we cannot conclude whether the $\mathrm{H}$ or $\mathrm{F}$ samples significantly differ in T-RFLP or represent outliers in the analysis.

To analyze the sensitivity of the PCA for such outliers further, we tested whether one prominent band could change the position of the sample in the PCA plot. Hereto, we decided to artificially change the intensity of the

Fig. 1 Bacterial community structure of agriculture topsoil sampled at different time points during 1 year. a T-RFLP profiles of amplified $16 \mathrm{~S}$ rRNA gene fragments in the different samples $(A-H)$, restricted with HaeIII and labeled with IRD-800 at the primer 926R. a2 Magnification of the region between 280-360 bp. b T-RFLP profiles of the same samples using restricted amplified 16S rRNA gene fragments labeled with IRD-700 at the forward primer $16 \mathrm{~S} 8 \mathrm{~F}$ and its magnified region (b2). Molecular size markers (in bp) are indicated on the left. c Examples of average relative intensities (among triplicates) of selected tRFs throughout the sampling year. Lanes $A-H$ denote different time points of soil sampling and correspond to those of the PCA (Fig. 3, Table 1); with $(a b c)$ representing replicates 


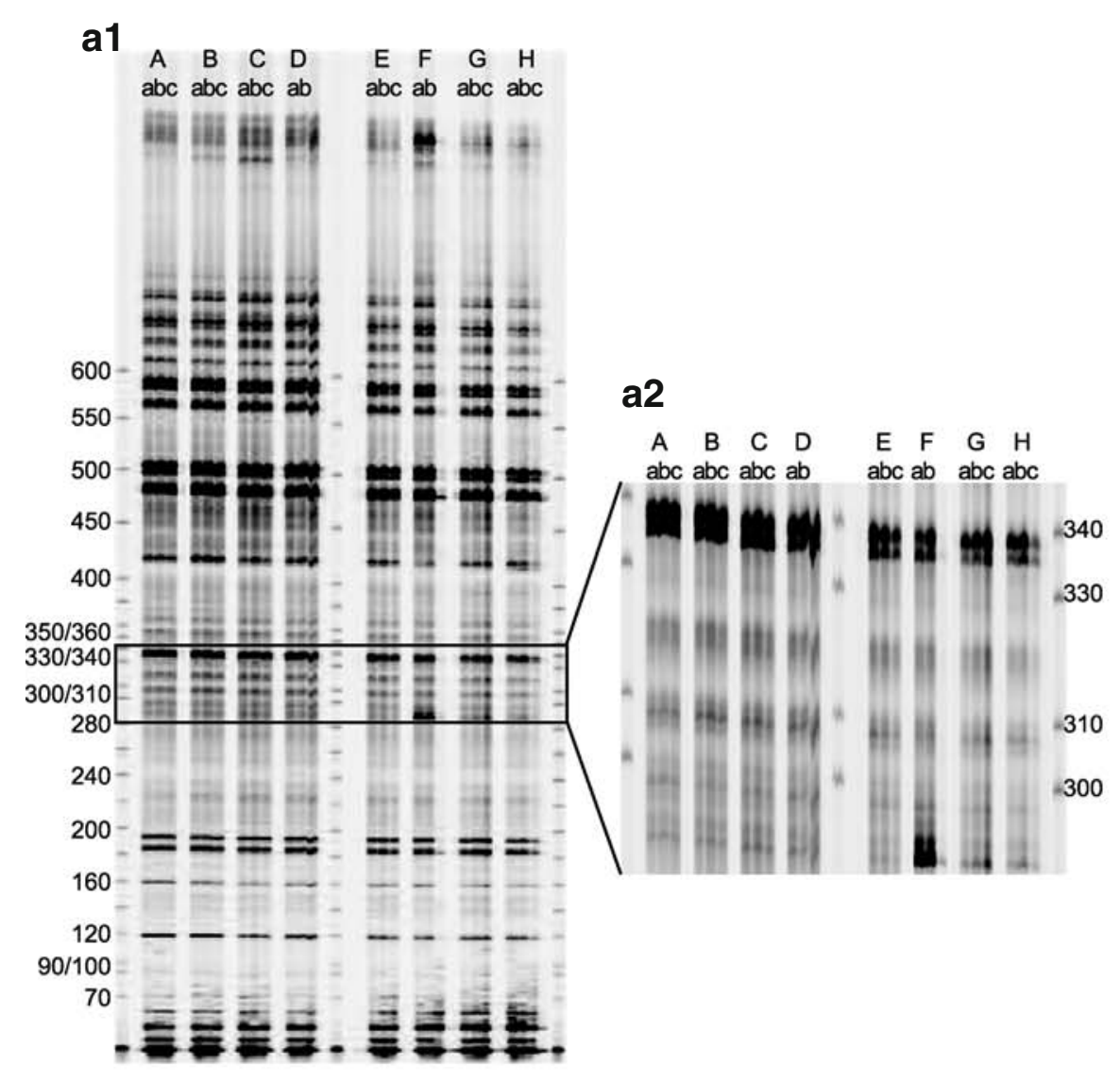

C
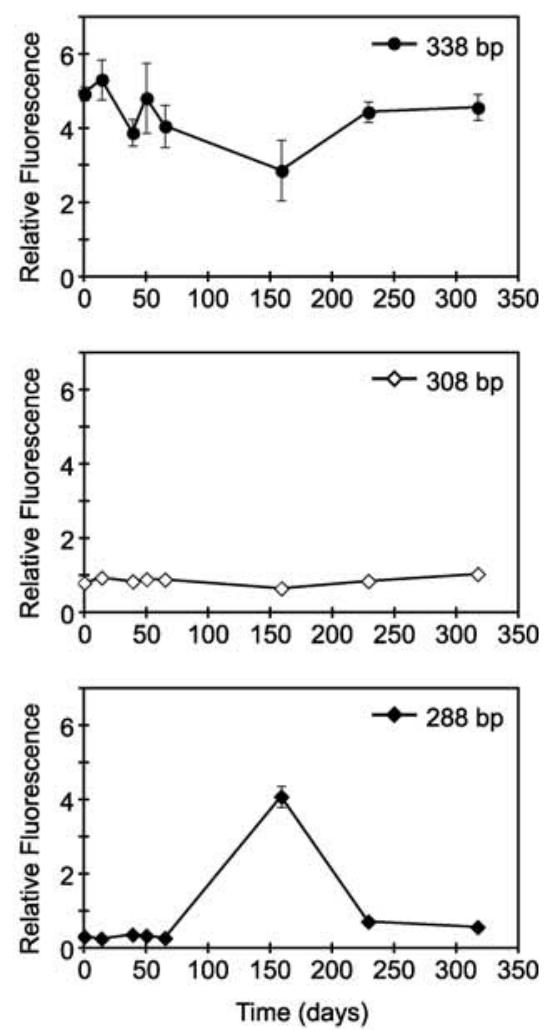

b1

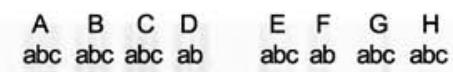

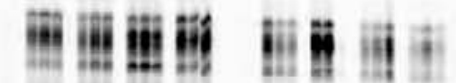
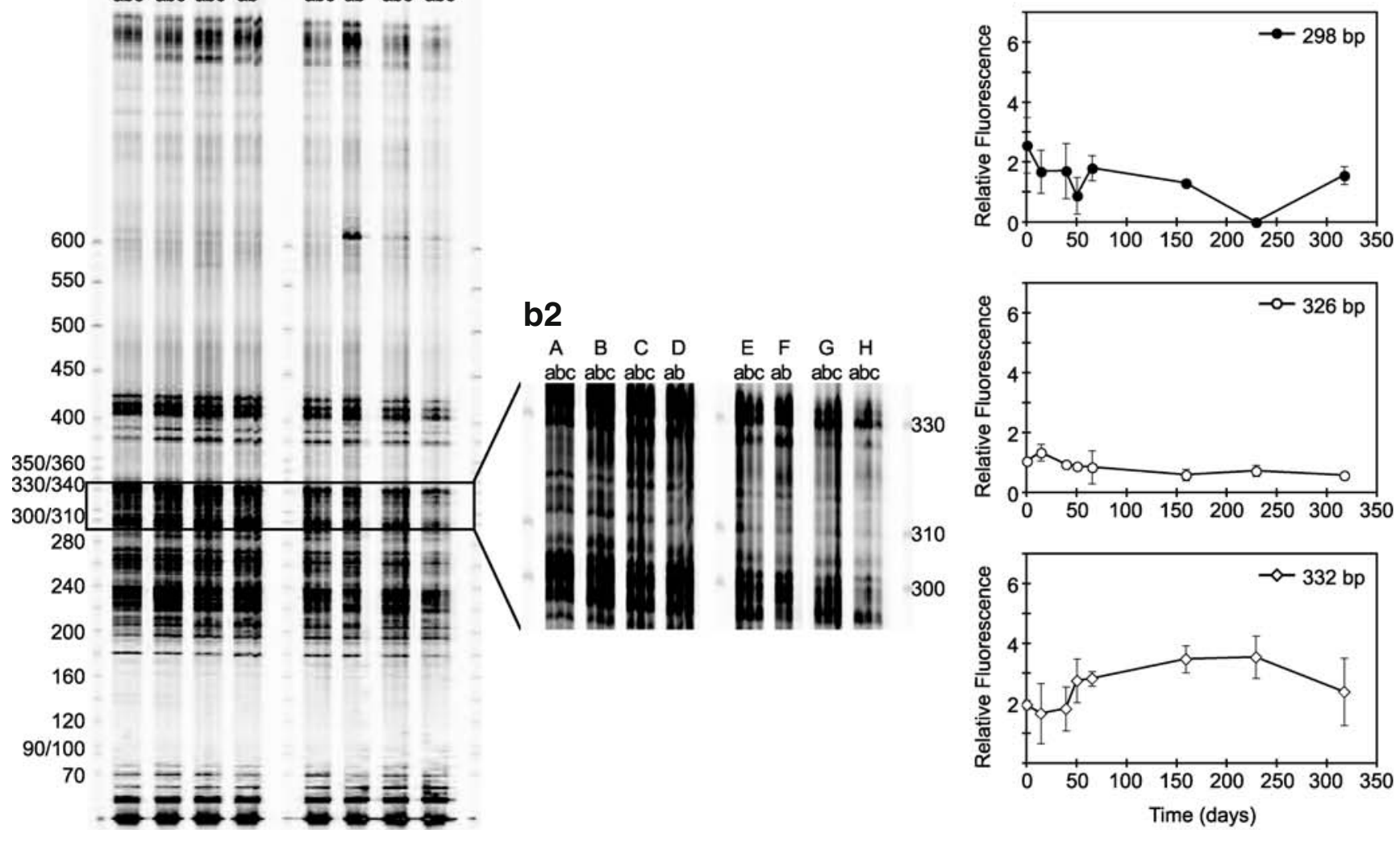
visually strong band at $288 \mathrm{bp}$ in the F samples (IRD-800) from a relative intensity of 4.3 and 3.9 to 0.40 (average intensity value of the other samples). In the PCA plot, this resulted in the clustering of the $\mathrm{F}$ samples with the others $\left({ }^{*} \mathrm{~F} 1\right.$ and ${ }^{*} \mathrm{~F} 2$ in Fig. $\left.2 \mathrm{a}\right)$, suggesting that its original position was solely determined by the intensity of this individual band. Similarly, when the relative band intensities at $614 \mathrm{bp}$ in the samples F1 and F2 (IRD-700) were substituted by the average values of the other samples, the $\mathrm{F}$ data points shifted to a position closer to the rest of the samples (*F1 and *F2 in Fig. $2 b)$.

Artificial Disturbance of the Microbial Community in Soil

To better interpret the magnitudes of seasonal variations observed in the soil microbial community of the agricultural field, we analyzed community changes in artificially perturbed laboratory microcosms containing the same soil by T-RFLP. These were short-period incubations with the only purpose of producing bacterial community changes and not to mimic seasonal developments in the field. As for the field samples, the tRF patterns of the control microcosm (S, soil with water added only) did not show major changes in number of detected bands, the calculated diversity index, and the Pearson's pairwise similarity coefficient (Table 4), showing that despite small microcosm size, no changes were induced by the system setup. Compared to the control, the addition of the bacteria $S$. herbicidivorans $\mathrm{MH}$ (B) without or with mecoprop (BM) caused an increase in phylotype richness (Table 4) but a significant temporary decrease in diversity index, between days 1 and 7, after which the diversity index returned to a similar level as at the beginning of the incubation. In addition, similarity coefficients decreased strongly for samples taken at days 1 and 2, compared to the time zero sample, after which, however, the similarities recovered (Table 4). Soil samples to which S. herbicidivorans strain MH was inoculated (B) showed a large increase in relative intensity of a fragment at $382 \mathrm{bp}$ in the IRD-700 profile and at $480 \mathrm{bp}$ in the IRD- 800 profile after 1 and 2 days of incubation (Figs. S2a, c and S3). The 480-bp band corresponds to an obtained fragment size (490 bp) when performing T-RFLP for the 16S rRNA gene on $S$. herbicidivorans genomic DNA (not shown). This effect was also observed in the tRF patterns of soils treated with mecoprop and inoculated with bacteria (BM, Fig. S4). Phylotype richness and diversity index in the nutrient-amended soil (NB) decreased strongly at day 1 but returned to a similar value as on day 0. Even visually, nutrient amendment resulted in large tRF differences (Fig. S5). On the contrary, profile similarities compared to the time zero sample decreased at day 1 and remained strongly dissimilar hereafter (Table 4).

PCA and bootstrapping analysis of the control soil community showed a strong clustering of all samples with very slight time variability (Fig. 4, Fig. S6). Inoculation of $S$. herbicidivorans strain MH quickly resulted in a strong

Table 2 Comparative statistical data on bacterial $16 \mathrm{~S}$ rRNA gene profiles obtained with T-RFLP at different time points during the year

\begin{tabular}{|c|c|c|c|c|c|c|c|c|c|}
\hline \multirow[t]{2}{*}{ Dataset } & \multicolumn{5}{|l|}{ IRD-700 } & \multicolumn{4}{|l|}{ IRD-800 } \\
\hline & $\begin{array}{l}\text { Pearson's } \\
\text { pairwise } \\
\text { similarity } \\
\text { coefficient }\end{array}$ & $\begin{array}{l}\text { Number of } \\
\text { significant } \\
\text { band } \\
\text { differences }{ }^{\mathrm{a}}\end{array}$ & $\begin{array}{l}\text { Number of } \\
\text { bands with } \\
\text { less than } 0.2- \\
\text { fold change } \\
\text { [minimum }]^{\mathrm{b}, \mathrm{d}}\end{array}$ & $\begin{array}{l}\text { Number of } \\
\text { bands with } \\
\text { more than } \\
\text { fivefold } \\
\text { change } \\
\text { [maximum] }{ }^{\mathrm{c}, \mathrm{d}}\end{array}$ & $\begin{array}{l}\text { Number of } \\
\text { new or } \\
\text { disap- } \\
\text { pearing } \\
\text { bands in } \\
\text { subsequent } \\
\text { sample }\end{array}$ & $\begin{array}{l}\text { Pearson's } \\
\text { pairwise } \\
\text { similarity } \\
\text { coefficient }\end{array}$ & $\begin{array}{l}\text { Number of } \\
\text { significant } \\
\text { band } \\
\text { differences }^{\mathrm{a}}\end{array}$ & $\begin{array}{l}\text { Number of } \\
\text { bands with } \\
\text { less than } 0.2- \\
\text { fold change } \\
\text { [minimum }]^{\mathrm{b}, \mathrm{d}}\end{array}$ & $\begin{array}{l}\text { Number of } \\
\text { bands with } \\
\text { more than } \\
\text { fivefold } \\
\text { change } \\
\text { [maximum] }\end{array}$ \\
\hline$A \times B$ & 0.928 & $28(n=114)$ & $8[0.021]$ & 8 [18.2] & $1 / 2$ & 0.989 & $12(n=37)$ & 0 & 0 \\
\hline $\mathrm{B} \times \mathrm{C}$ & 0.832 & $41(n=111)$ & $8[0.011]$ & 11 [18.7] & $3 / 3$ & 0.980 & $9(n=37)$ & 0 & 0 \\
\hline $\mathrm{C} \times \mathrm{D}$ & 0.823 & - & $14[0.008]$ & 19 [290] & $4 / 6$ & 0.976 & - & 0 & 0 \\
\hline $\mathrm{C} \times \mathrm{E}$ & - & $10(n=125)$ & - & - & - & - & $0(n=37)$ & - & - \\
\hline $\mathrm{D} \times \mathrm{E}$ & 0.958 & - & 8 [0.003] & 13 [130] & $4 / 2$ & 0.989 & - & 0 & 0 \\
\hline $\mathrm{E} \times \mathrm{F}$ & 0.417 & - & $13[0.053]$ & 9 [358] & $5 / 7$ & 0.953 & - & $1[0.06]$ & 0 \\
\hline $\mathrm{E} \times \mathrm{G}$ & - & $18(n=125)$ & - & - & - & - & $12(n=37)$ & - & - \\
\hline $\mathrm{F} \times \mathrm{G}$ & 0.494 & - & $12[0.002]$ & 15 [111] & $13 / 9$ & 0.952 & - & 0 & 3 [13.1] \\
\hline $\mathrm{G} \times \mathrm{H}$ & 0.871 & - & $15[0.011]$ & 15 [51] & $8 / 5$ & 0.909 & - & 0 & $1[6.5]$ \\
\hline $\mathrm{H} \times \mathrm{A}$ & 0.866 & - & - & - & $2 / 7$ & 0.913 & - & - & - \\
\hline
\end{tabular}

${ }^{a} P<0.05$, pairwise $t$ test, number of corresponding significant changes in two datasets: 12 , in three datasets: 5 , in four datasets: 0

${ }^{b}$ Number of bands less than 0.2 -fold in two datasets: 15 , in three datasets: 3 , in four or more: 0

${ }^{\mathrm{c}}$ Number of bands more than fivefold in two datasets: 24 , in three or more: 0

${ }^{\mathrm{d}}$ Number of bands less than 0.2 -fold and more than fivefold in two datasets: 12 , three datasets: 17 , four datasets: 9 , five datasets: 1 


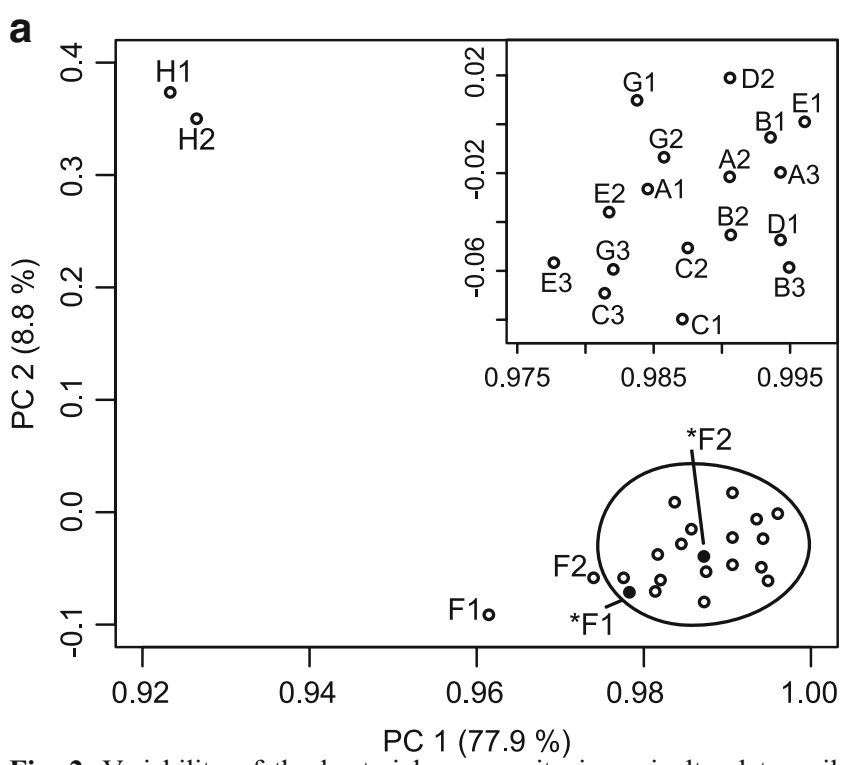

Fig. 2 Variability of the bacterial community in agricultural topsoil over time during 1 year. a Principle components analysis of the relative band intensities of all tRFs using the IRD-800-primed amplicons. The first two components contribute to $86.7 \%$ of the total variation. b PCA of relative band intensities of tRFs using the IRD700 primed amplicons; components 1 and 2 are responsible for $97.6 \%$ of the total variation. The regions within the ellipses are enlarged in

and significant shift of the community (compare data points B0 with B1 and B2 in Figs. 4a and S6), slowly returning to the original composition and that of the community in the control incubations, on days 7 and 14 (Fig. 4a). Both IRD700 and IRD-800 datasets were in good agreement in Mantel permutation tests $(0.87, P=0.01$, Table 3$)$. Inocula-

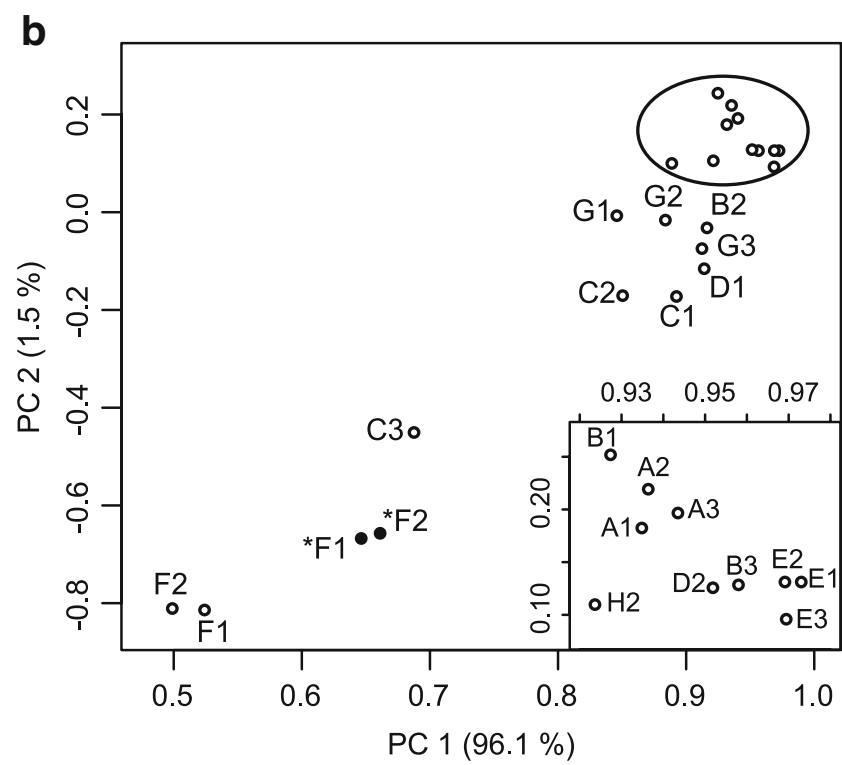

the inset for clarity. Lettering $(A-H)$ corresponds to sample designations as in Fig. 1 and Table 1. Indices refer to the different replicates per sample. ${ }^{*} \mathrm{~F} 1$ and ${ }^{*} \mathrm{~F} 2$ in panels $\mathbf{a}$ and $\mathbf{b}$ show the shifts of the data points after the artificial relative intensity change of the bands at 288 (IRD-800) and $614 \mathrm{bp}$ (IRD-700) as explained in the main text. Note the scale differences between $\mathbf{a}$ and $\mathbf{b}$ and between the enlarged regions

tion with bacteria and application of mecoprop (BM) immediately resulted in a detectable community change, which augmented after day 2 and continued to be different from both control and time zero and day 1 samples (Figs. 4b, S7). Note, however, that the magnitude of the temporarily change in Euclidean distance between the
Fig. 3 Sample clustering of the agricultural topsoil bacterial community profiles using distance matrix calculations and bootstrapping. a Clustering based on the T-RFLP dataset obtained with the 8 F IRD-700 forward-primed 16S rRNA gene amplicons. b Idem with the 927R IRD-800 reverse-primed amplicons. The ordinate shows the Euclidean distance, and numbers at the nodes refer to the percentage of trees carrying this branching order as obtained via bootstrapping $(n=100)$. Sample designations (lettering plus index) correspond to those of Figs. 1 and 2 and Table 1
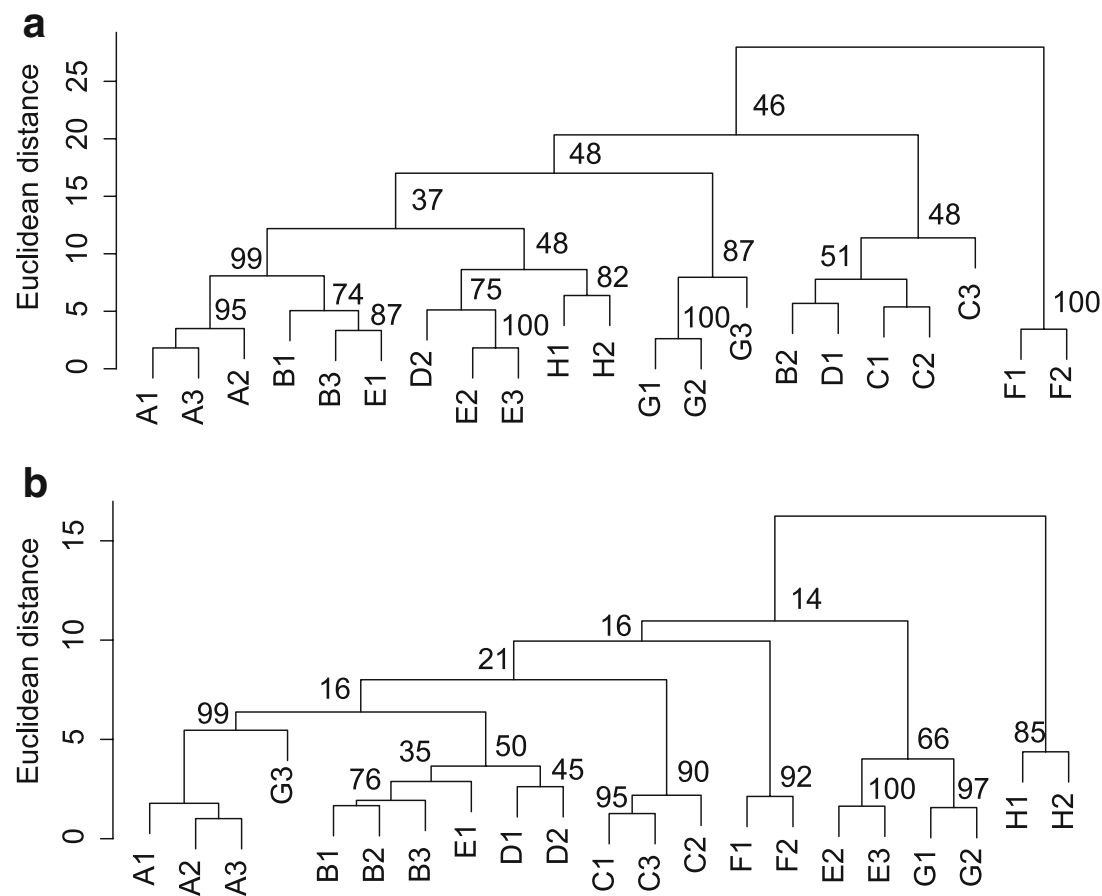
Table 3 Correlation of distance matrices of bacterial 16S rRNA gene profiles obtained with T-RFLP

\begin{tabular}{lll}
\hline Dataset & Simulated similarity $^{\mathrm{a}}$ & ${\text { Simulated } P \text { value }^{\mathrm{b}}}$ \\
\hline $\mathrm{dd} 700 \times \mathrm{dd} 800^{\mathrm{c}}$ & 0.42 & 0.01 \\
$\mathrm{~s} 700 \times \mathrm{s} 800$ & 0.29 & 0.02 \\
$\mathrm{nb} 700 \times \mathrm{nb} 800$ & 0.87 & 0.01 \\
$\mathrm{~b} 700 \times \mathrm{b} 800$ & 0.87 & 0.01 \\
$\mathrm{~b} 7700 \times \mathrm{bm} 800$ & 0.84 & 0.01
\end{tabular}

${ }^{\text {a }}$ Similarity value produced from 999 repetitions in a Monte Carlo permutation test

${ }^{\mathrm{b}}$ Simulated significance value

${ }^{\mathrm{c}}$ Datasets: $d d 700$ T-RFLP data IRD-700 channel (primer 6F) from soil community DNA, $d d 800$ idem IRD-800 (primer 926R), s700 soil microcosm, $n b 700$ soil microcosm with nutrient broth added, $b 700$ soil microcosm with bacteria inoculated, $b m 700$ soil microcosm with bacteria plus mecoprop added

incubation with bacteria only (B) was larger than with mecoprop plus bacteria (BM). Cluster analysis reinforced the visual observations that nutrient addition resulted in an immense and immediate effect on the bacterial community composition and did not return to the control composition either (Figs. 4c, S8). Surprisingly, the variation between communities from the NB treatment completely surpassed that of the others. Both IRD-800 and IRD-700 datasets for the NB treatment samples were again in good agreement (0.87, $P=0.01$, Table 3$)$. In terms of pairwise dataset comparisons, almost $25 \%$ of the tRFs between NB treatment and control were unique to either dataset, vs up to $5 \%$ for bacterial inoculation with or without mecoprop compared to the control (Table 5).

\section{Discussion}

\section{Natural Variability}

In this paper, we studied bacterial community fluctuations in a regular agricultural soil as a function of seasonal influences and human activities. Detecting such "natural" variations is important because they form the baseline against which changes in microbial diversity can be detected. For example, we might be interested in inoculating specific bacteria for bioremediation of agricultural chemicals, but possible negative effects on microbial diversity must be related to a background of natural variability. Various authors have reported that the inherent relative band intensity deviation among replicate T-RFLP analyses is in the order of between 5 and $15 \%[1,16,33]$, with sample replicate similarity indices of between 0.85 to 0.97 , which is similar to what we found here. Fluctuations in community profiles, which are smaller than the inherent method variability, can thus not be discerned, except when

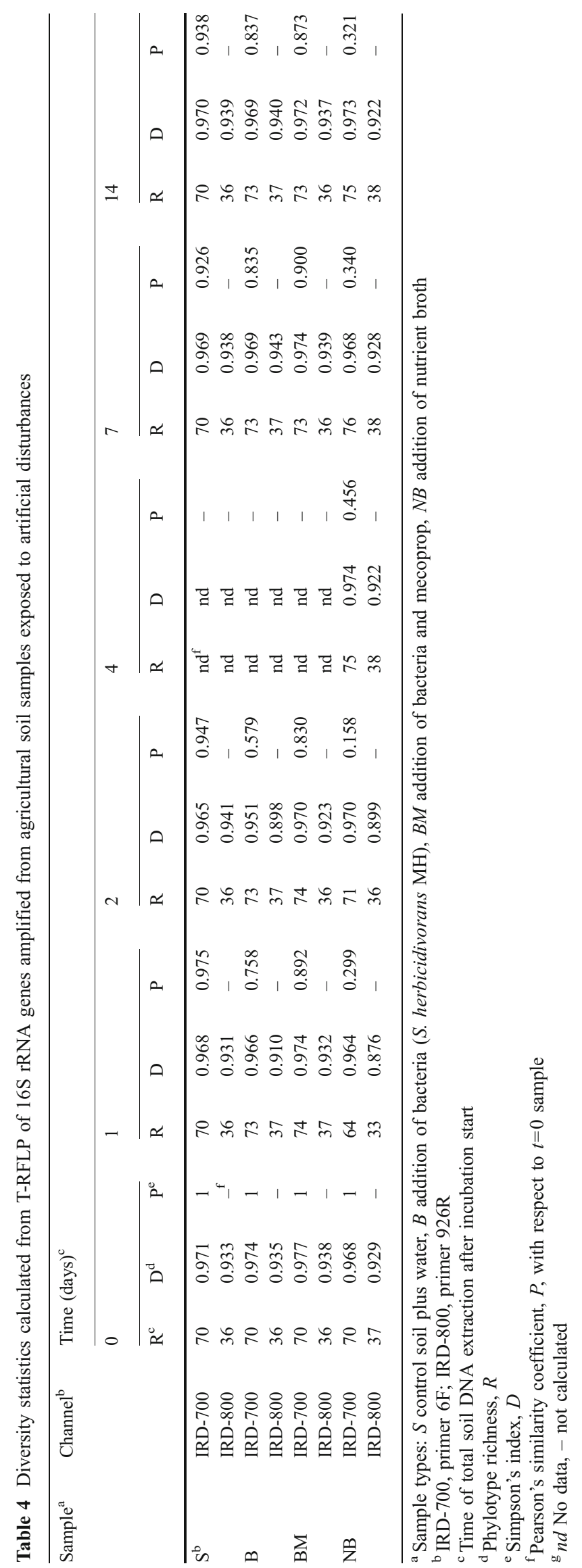


the number of replicate analyses is increased. It is interesting to note that the bacterial community in the soil as examined via variability of the $16 \mathrm{~S}$ rRNA genes and $16 \mathrm{~S}-23 \mathrm{~S}$ rRNA intergenic spacer region using T-RFLP and RISA, respectively, remained overall highly constant during the seasons (with changing temperature and rainfall) and despite human activities (plowing, maize and winter lettuce, fertilization). The highly stable bacterial community is well documented by the overall community parameters richness and Simpson's diversity indices and by PCA, clustering, and bootstrapping on complete tRF datasets. There was a tendency for the December sample ("F") to be different from the rest (Table 2), but IRD-700 and IRD-800 datasets did not consistently place this sample outside the rest. One component in PCA was largely sufficient to explain the variability among the samples but did not correlate with the sampling date or season itself. Clustering and bootstrapping of distance matrices suggested that none of the clustering branches was significant (i.e., occurring in more than $50 \%$ of the bootstrapped trees) or occurred similarly in both IRD-700 and IRD-800 datasets, implying that the sampled communities do not follow a clear trend and thus remain the same in statistical terms. Because we sampled more or less randomly in time, we may have missed changes resulting from rainfall, which were already leveled out at the time of sampling. However, other authors have reported that normal soil moisture fluctuations (drought and rewetting) have relatively little effect on bacterial community composition as measured by $16 \mathrm{~S}$ rRNA gene or transcript diversity [14].

Nevertheless, a significant number of individual tRFs did vary in relative intensity (Fig. 1, Table 2), both for the IRD-700 and the IRD-800 datasets, and there was a slight tendency that samples E, F, and G (fall, winter, and spring) were more variable in number of unique differences (Table 2). This and the magnitude of some tRF fluctuations (up to 358-fold) leads us to conclude that individual populations within the soil microbial community do vary, whereas this may be leveled out at the variance level of all tRFs. We are aware that a single tRF in the analysis can actually be comprised from different bacterial populations, which happen to have the same restriction cleavage position in their $16 \mathrm{~S}$ rRNA gene with respect to the PCR primerbinding site and that, therefore, even a nonchanging tRF in the analysis may be the consequence of fluctuating subpopulations. In addition, misinterpretations may occur in band designations in particular among similarly sized bands [33] and as a result of PCR artifacts [10]. For the time being and without further information on the tRFs sequences, therefore, we do not assign specifically fluctuating tRFs to particular bacterial populations. This problem, although, is partially overcome at the level of the complete datasets by the use of both end-labeled-amplified $16 \mathrm{~S}$ rRNA gene fragments.
Detecting Community Changes

We could thus conclude that the soil bacterial community overall did not change significantly (within the limits and sensitivity set by the inherent method variability and accuracy of T-RFLP or RISA), whereas a limited number of individual bacterial populations did vary (Table 2). Not many studies have specifically addressed natural community fluctuations in soil microbiota, and those which did reported contradicting results or applied different methodologies and statistical analyses. For example, the soil microbial communities in a pine forest soil in Java were shown to remain stable throughout a wet and a dry season but differed according to soil organic carbon content [21], whereas Laverman et al. [23] concluded that populations of ammonium-oxidizing bacteria remained stable throughout the year in a temperate, acid forest soil, although the total bacterial community structure dramatically differed. In the previously mentioned studies of Buckley and Schmidt [3] and Lipson and Schmidt [26], significant changes in taxonomic group sizes of soil bacterial communities were detected during the seasons, amounting to approximately twofold increase or decrease per taxonomic group. However, of the four reports, Krave et al. [21] employed rRNA rather than $16 \mathrm{~S}$ rRNA gene abundance, whereas none of the other reports included community-wide statistical analysis, making comparisons about the magnitude of changes rather difficult. Because clear community differences were observed in long-term studies between differently treated soils, several authors concluded that soil communities respond at time scales of 10 or more years [3, 22, 44], which would also suggest that seasonal changes in community composition remain small.

To relate the magnitudes of observed T-RFLP variations in the agricultural soil bacterial community to some experimental parameter and perhaps define a "bandwidth" of natural variability, we subjected soil in microcosms to a number of artificial laboratory-induced perturbations, which we expected would lead to a measurable difference in community composition. Inoculation of $10^{9}$ bacteria $(S$. herbicidivorans $\mathrm{MH}$ ) to $2 \mathrm{~g}$ soil resulted in a very clearly differentiated community profile compared to a control soil, incubated under the same conditions. On the other hand, addition of water only and incubating for 14 days at $25^{\circ} \mathrm{C}$ did not significantly change the bacterial community profile. It is interesting to note that bacterial communities perturbed with inoculated bacteria returned to their original community profile after 7 days and the 480-bp band attributed to the $16 \mathrm{~S}$ rRNA gene of $S$. herbicidivorans $\mathrm{MH}$ disappeared, which may indicate that the inoculated bacteria did not survive well in the soil. Adding both bacteria and mecoprop (a frequently used herbicide in agricultural practice) changed the community profile to a 

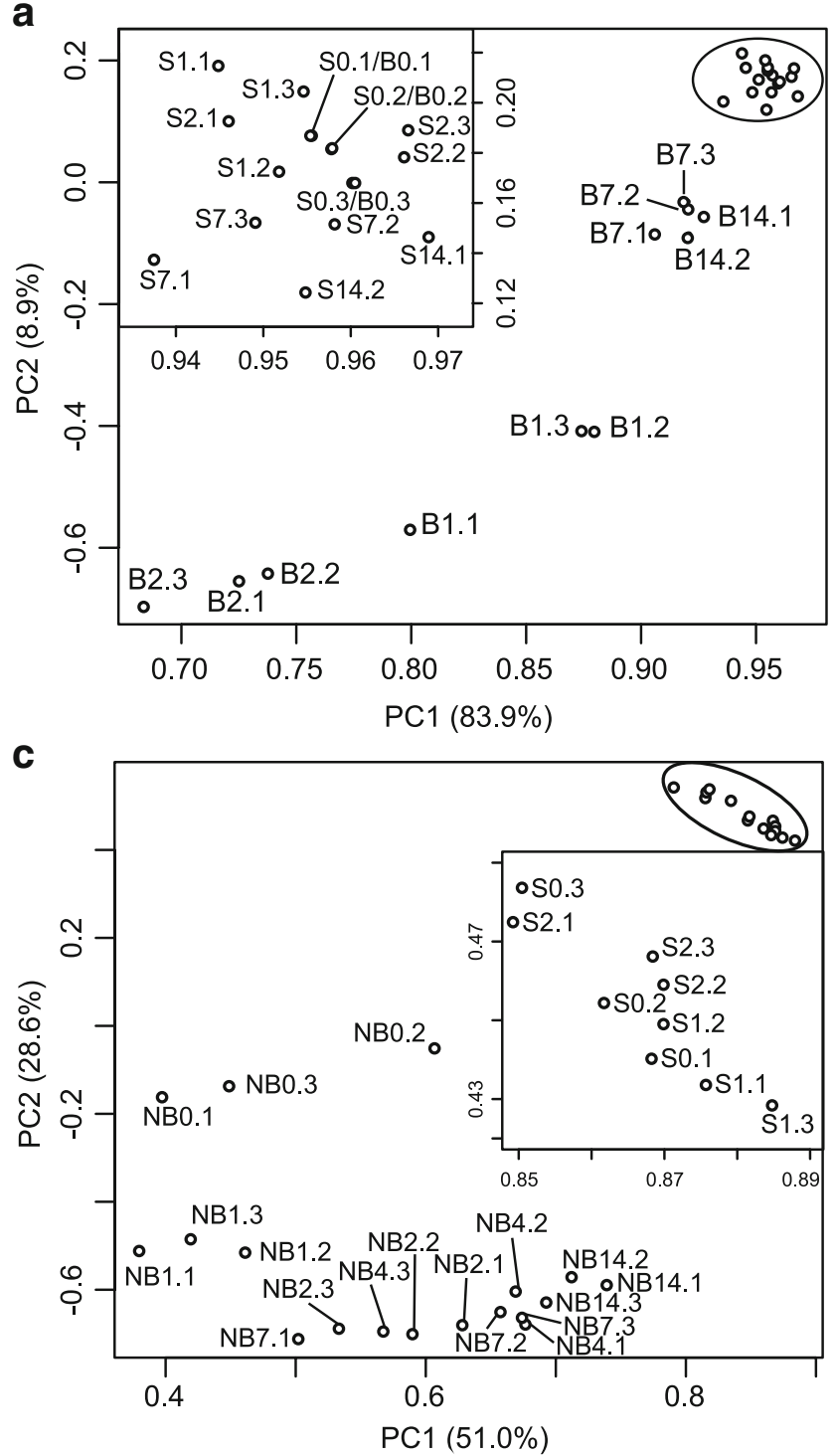

Fig. 4 PCAs of relative band intensities of the IRD-700 datasets from the soil microcosms. Different individual treatments are compared. a $S$ (control soil plus water) vs $B$ (addition of $S$. herbicidivorans bacteria), b $S$ vs $B M$ (bacteria and mecoprop), and c $S$ vs $N B$ (addition of

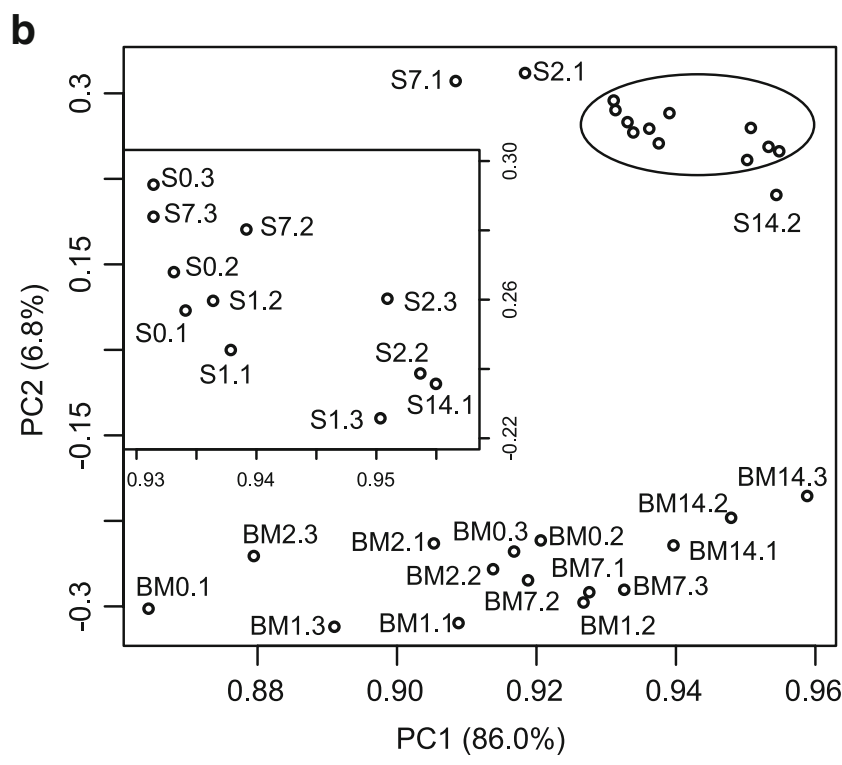

nutrient broth). PC 1 is plotted against PC 2. The two main components explain 92.8 (a), 92.8 (b), and $79.6 \%$ (c) of the total variation. Encircled data points are enlarged in separate plots. Note the scale differences of the components among the three plots

Table 5 Number of changing labeled terminal restriction fragments between different treatments to soil in microcosms

\begin{tabular}{lllll}
\hline Dataset & \multicolumn{2}{l}{ IRD-700 $^{\mathrm{a}}$} & \multicolumn{2}{l}{ IRD-800 } \\
\cline { 2 - 5 } & Number of new tRFs $^{\mathrm{b}}$ & Disappearing $^{\mathrm{c}}$ & & Number of new bands \\
\hline $\mathrm{S} \times \mathrm{NB}$ & $25(n=95)^{\mathrm{d}}$ & 13 & $11(n=47)$ & 8 \\
$\mathrm{~S} \times \mathrm{B}$ & $4(n=75)$ & 0 & $1(n=38)$ & 0 \\
$\mathrm{~S} \times \mathrm{BM}$ & $5(n=75)$ & 0 & $0(n=38)$ & 1 \\
\hline
\end{tabular}

a $I R D-700$ primer $6 \mathrm{~F}, I R D-800$ primer $926 \mathrm{R}$

${ }^{\mathrm{b}}$ tRFs appearing in NB, B, or BM vs $\mathrm{S}$ across all time samples

${ }^{\mathrm{c}}$ Idem disappearing in $\mathrm{NB}, \mathrm{B}$, or $\mathrm{BM}$ vs $\mathrm{S}$

${ }^{d}$ Total number of tRFs in both datasets 
lesser extent than bacteria only but to a permanently different state after 14 days. Both these treatments, therefore, suggested that the soil community in the field did not fluctuate as much as the equivalent of inoculation of one strain at $10^{9}$ cells or addition of $4 \mu \mathrm{g}$ mecoprop per gram soil. To put this in perspective, in a recent semifield-scale bioremediation study, Paul et al. [34] used $10^{6}$ Arthrobacter cells per gram of soil and found no significantly different community profiles compared to a noninoculated control. Perhaps as an extreme, addition of nutrients changed the community composition immediately and for the full duration of the incubation. This perturbation is similar in effect as plating soil bacteria suspensions on nutrient agar in which case the resulting colony diversity no longer corresponds to the original community diversity [40].

Can a bandwidth of natural variability thus be defined, outside which the community will develop into a different composition? The first difficulty in this respect is to identify the proper parameter for the bandwidth definition. Zhou et al. [45] described no diversity differences in a soil polluted with $20 \%$ chromium using the reciprocal of the Simpson's and the log series index, whereas soils from different depths and locations did differ. The results of this work and that of others [16] suggest that classical diversity parameters (species richness, Simpson's diversity) are not sufficient for this purpose, at least not in combination with T-RFLP data that generate some 100 observations per sample (i.e., number of tRFs in IRD-700 plus IRD-800 datasets). On the contrary, the use of a pairwise similarity index was proposed by De La Cochetière et al. [6], who studied community fluctuations in human intestinal flora in response to antibiotic treatment. It is interesting to note that their data suggested that at $\sim 70 \%$ community similarity (calculated from TGGE diversity of amplified 16S rRNA gene fragments), the communities still recover to their original composition [6]. Our perturbation experiments suggested that temporary similarities of $58 \%$ still recover, at least in the case of bacteria inoculation, whereas at $30 \%$ or less, the communities will differ in the long term (Table 4, Fig. 4). However, the use of similarity indices is not completely satisfying because it cannot differentiate composition trends very well (viz. the different trends between communities perturbed with bacteria alone or bacteria plus mecoprop). In this paper, the use of coordinate analysis (or PCA) or other types of clustering become more appropriate [1, 16, 17], although quantitative boundary definitions become much more difficult. In terms of "pragmatic" definition, therefore, the use of similarity indices or correlation coefficients between distance matrices may be favored in which case the $70 \%$ similarity boundary may be proposed as a rule of thumb for bacterial communities starting to drift apart. It may be interesting to test further types of experimental perturbations to better define the resilience of complex microbial communities via similarity or correlation coefficients, which may have a more general character for any complex bacterial community. Furthermore, we can conclude that soil microbial communities appear to fluctuate insignificantly at the level of T-RFLP analysis during the various seasons, which offers good possibilities to detect future aberrant trends.

Acknowledgments This work was supported by a grant from the COST program 830 "Microbial inoculants in agriculture and environment." The authors greatly appreciate the help of Jerôme Goudet and Nicolas Salamin of the University of Lausanne in the principal components analysis, bootstrapping, and usage of R. Hans-Ruedi Pfeifer is thanked for soil chemical analysis and Franco Widmer for critical comments on the manuscript and for suggestions on improvement.

\section{References}

1. Ayala-del-Rio HL, Callister SJ, Criddle CS, Tiedje JM (2004) Correspondence between community structure and function during succession in phenol- and phenol-plus-trichloroethene-fed sequencing batch reactors. Appl Environ Microbiol 70:4950-4960

2. Bossio DA, Scow KM, Gunapala N, Graham KJ (1998) Determinants of soil microbial communities: effects of agricultural management, season, and soil type on phospholipid fatty acid profiles. Microb Ecol 36:1-12

3. Buckley DH, Schmidt TM (2003) Diversity and dynamics of microbial communities in soils from agro-ecosystems. Environ Microbiol 5:441-452

4. Bürgmann H, Pesaro M, Widmer F, Zeyer J (2001) A strategy for optimizing quality and quantity of DNA extracted from soil. J Microbiol Meth 45:7-20

5. Chessel D, Dufour A-B, Dray S (2006) The ade4 package: analysis of environmental data, exploratory and euclidean methods in environmental sciences. Available at: http://pbil.univ-lyon1. fr/ADE-4

6. De La Cochetière MF, Durand T, Lepage P, Bourreille A, Galmiche JP, Doré J (2005) Resilience of the dominant human fecal microbiota upon short-course antibiotic challenge. J Clin Microbiol 43:5588-5592

7. Duineveld BM, Rosado AS, van Elsas JD, van Veen JA (1998) Analysis of the dynamics of bacterial communities in the rhizosphere of the chrysanthemum via denaturing gradient gel electrophoresis and substrate utilization patterns. Appl Environ Microbiol 64:4950-4957

8. Dunbar J, Ticknor LO, Kuske CR (2000) Assessment of microbial diversity in four southwestern united states soils by $16 \mathrm{~S}$ rRNA gene terminal restriction fragment analysis. Appl Environ Microbiol 66:2943-2950

9. Fisher MM, Triplett EW (1999) Automated approach for ribosomal intergenic spacer analysis of microbial diversity and its application to freshwater bacterial communities. Appl Environ Microbiol 65:4630-4636

10. Frey JC, Angert ER, Pell AN (2006) Assessment of biases associated with profiling simple, model communities using terminal-restriction fragment length polymorphism-based analyses. J Microbiol Methods 67:9-19

11. Gans J, Wolinsky M, Dunbar J (2005) Computational improvements reveal great bacterial diversity and high metal toxicity in soil. Science 309:1387-1390

12. Gelsomino A, Keijzer-Wolters AC, Cacco G, van Elsas JD (1999) Assessment of bacterial community structure in soil by polymer- 
ase chain reaction and denaturing gradient gel electrophoresis. $\mathrm{J}$ Microbiol Methods 38:1-15

13. Girvan MS, Campbell CD, Killham K, Prosser JI, Glover LA (2005) Bacterial diversity promotes community stability and functional resilience after perturbation. Environ Microbiol 7:301-313

14. Griffiths RI, Whiteley AS, O, Donnell AG, Bailey MJ (2003) Physiological and community responses of established grassland bacterial populations to water stress. Appl Environ Microbiol 69:6961-6968

15. Hamel C, Hanson K, Selles F, Cruz AF, Lemke R, McConkey B, Zentner R (2006) Seasonal and long-term resource-related variations in microbial communities in wheat-based rotations of the canadian prairie. Soil Biol Biochem 38:2104-2116

16. Hartmann M, Frey B, Kölliker R, Widmer F (2005) Semiautomated genetic analysis of soil microbial communities: Comparison of T-RFLP and RISA based on descriptive and discriminative statistical approaches. J Microbiol Methods 61:349-360

17. Hartmann M, Widmer F (2006) Community structure analyses are more sensitive to differences in soil bacterial communities than anonymous diversity indices. Appl Environ Microbiol 72:7804-7812

18. Horvath M, Ditzelmüller G, Loidl M, Streichsbier F (1990) Isolation and characterization of a 2-(2,4-dichlorophenoxy) propionic acid-degrading soil bacterium. Appl Microbiol Biotechnol 33:213-216

19. King S, McCord BR, Riefler RG (2005) Capillary electrophoresis single-strand conformation polymorphism analysis for monitoring soil bacteria. J Microbiol Methods 60:83-92

20. Kohler HPE (1999) Sphingomonas herbicidovorans MH: A versatile phenoxyalkanoic acid herbicide degrader. J Ind Microbiol Biotechnol 23:336-340

21. Krave AS, Lin B, Braster M, Laverman AM, van Straalen NM, Roling WF, van Verseveld HW (2002) Stratification and seasonal stability of diverse bacterial communities in a Pinus merkusii (pine) forest soil in central Java, Indonesia. Environ Microbiol 4:361-373

22. Kuske CR, Ticknor LO, Miller ME, Dunbar JM, Davis JA, Barns SM, Belnap J (2002) Comparison of soil bacterial communities in rhizospheres of three plant species and the interspaces in an arid grassland. Appl Environ Microbiol 68:1854-1863

23. Laverman AM, Speksnijder AG, Braster M, Kowalchuk GA, Verhoef HA, Van Verseveld HW (2001) Spatiotemporal stability of an ammonia-oxidizing community in a nitrogen-saturated forest soil. Microb Ecol 42:35-45

24. Lee DH, Zo YG, Kim SJ (1996) Nonradioactive method to study genetic profiles of natural bacterial communities by PCR-singlestrand-conformation polymorphism. Appl Environ Microbiol 62:3112-3120

25. Li Z, Xu J, Tang C, Wu J, Muhammad A, Wang H (2006) Application of 16S rDNA-PCR amplification and DGGE fingerprinting for detection of shift in microbial community diversity in $\mathrm{Cu}-, \mathrm{Zn}-$, and Cd-contaminated paddy soils. Chemosphere 62:1374-1380

26. Lipson DA, Schmidt SK (2004) Seasonal changes in an alpine soil bacterial community in the colorado rocky mountains. Appl Environ Microbiol 70:2867-2879

27. Liu WT, Marsh TL, Cheng H, Forney LJ (1997) Characterization of microbial diversity by determining terminal restriction fragment length polymorphisms of genes encoding 16S rRNA. Appl Environ Microbiol 63:4516-4522

28. Macbeth TW, Cummings DE, Spring S, Petzke LM, Sorenson KS Jr (2004) Molecular characterization of a dechlorinating community resulting from in situ biostimulation in a trichloroethene-contaminated deep, fractured basalt aquifer and comparison to a derivative laboratory culture. Appl Environ Microbiol 70:7329-7341

29. Marsh TL (1999) Terminal restriction fragment length polymorphism (T-RFLP): an emerging method for characterizing diversity among homologous populations of amplification products. Curr Opin Microbiol 2:323-327

30. Moeseneder MM, Arrieta JM, Muyzer G, Winter C, Herndl GJ (1999) Optimization of terminal-restriction fragment length polymorphism analysis for complex marine bacterioplankton communities and comparison with denaturing gradient gel electrophoresis. Appl Environ Microbiol 65:3518-3525

31. Muller AK, Westergaard K, Christensen S, Sorensen SJ (2001) The effect of long-term mercury pollution on the soil microbial community. FEMS Microbiol Ecol 36:11-19

32. Muyzer G, Smalla K (1998) Application of denaturing gradient gel electrophoresis (DGGE) and temperature gradient gel electrophoresis (TGGE) in microbial ecology. Antonie Van Leeuwenhoek 73:127-141

33. Osborn AM, Moore ER, Timmis KN (2000) An evaluation of terminal-restriction fragment length polymorphism (T-RFLP) analysis for the study of microbial community structure and dynamics. Environ Microbiol 2:39-50

34. Paul D, Pandey G, Meier C, van der Meer JR, Jain RK (2006) Bacterial community structure of a pesticide-contaminated site and assessment of changes induced in community structure during bioremediation. FEMS Microbiol Ecol 57:116-127

35. Ranjard L, Poly F, Combrisson J, Richaume A, Gourbiere F, Thioulouse J, Nazaret S (2000) Heterogeneous cell density and genetic structure of bacterial pools associated with various soil microenvironments as determined by enumeration and DNA fingerprinting approach (RISA). Microb Ecol 39:263-272

36. Ranjard L, Poly F, Lata JC, Mougel C, Thioulouse J, Nazaret S (2001) Characterization of bacterial and fungal soil communities by automated ribosomal intergenic spacer analysis fingerprints: Biological and methodological variability. Appl Environ Microbiol 67:4479-4487

37. Sambrook J, Fritsch EF, Maniatis T (1989) Molecular cloning: a laboratory manual. Cold Spring Harbor Laboratory, Cold Spring Harbor, NY

38. Schwarzenbach K, Enkerli J, Widmer F (2007) Objective criteria to assess representativity of soil fungal community profiles. $\mathrm{J}$ Microbiol Methods 68:358-366

39. Schwieger F, Tebbe CC (1998) A new approach to utilize PCRsingle-strand-conformation polymorphism for 16S rRNA genebased microbial community analysis. Appl Environ Microbiol 64:4870-4876

40. Torsvik V, Daae FL, Sandaa RA, Ovreas L (1998) Novel techniques for analysing microbial diversity in natural and perturbed environments. J Biotechnol 64:53-62

41. Torsvik V, Goksoyr J, Daae FL (1990) High diversity in DNA of soil bacteria. Appl Environ Microbiol 56:782-787

42. van Elsas JD, Duarte GF, Keijzer-Wolters A, Smit E (2000) Analysis of the dynamics of fungal communities in soil via fungal- specific PCR of soil DNA followed by denaturing gradient gel electrophoresis. J Microbiol Methods 43:133-151

43. Watanabe K, Kodama Y, Harayama S (2001) Design and evaluation of PCR primers to amplify bacterial $16 \mathrm{~S}$ ribosomal DNA fragments used for community fingerprinting. J Microbiol Methods 44:253-262

44. Widmer F, Rasche F, Hartmann M, Fliessbach A (2006) Community structures and substrate utilization of bacteria in soils from organic and conventional farming systems of the DOK longterm field experiment. Appl Soil Ecol 33:294-307

45. Zhou J, Xia B, Treves DS, Wu LY, Marsh TL, O, Neill RV, Palumbo AV, Tiedje JM (2002) Spatial and resource factors influencing high microbial diversity in soil. Appl Environ Microbiol 68:326-334

46. Zipper C, Bunk M, Zehnder AJB, Kohler HP (1998) Enantioselective uptake and degradation of the chiral herbicide dichlorprop [(rs)-2-(2,4-dichlorophenoxy)propanoic acid] by Sphingomonas herbicidovorans MH. J Bacteriol 180:3368-3374 